International Journal of Agriculture, Environment and Bioresearch

Vol. 4, No. 06; 2019

ISSN: $2456-8643$

\title{
MYCOFLORA AND NUTRITIONAL CONSTITUENTS OF GREEN PEA (Pisumsativum)
}

\author{
${ }^{1}$ Chuku, E. C. ${ }^{2}$ Emiri, U And ${ }^{1}$ Agbagwa, S.S \\ ${ }^{1}$ Department Of Plant Science And Biotechnology, Rivers State University. \\ ${ }^{2}$ Department Of Agricultural Education, Isaac Jasper Colledge Of Education, Sagbama, Bayelsa State, Nigeria \\ http://doi.org/10.35410/IJAEB.2019.4482
}

\begin{abstract}
Research on the mycoflora and nutritional constituents of P. sativum were carried out in the Department of Plant Science and Biotechnology, Rivers State University. Proximate investigation revealed the presence of moisture, ash, fibre, lipid, protein and carbohydrate in the

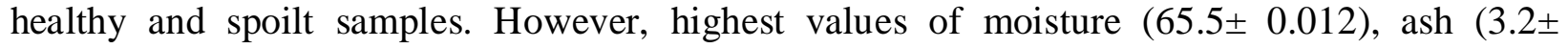
$00.004)$ and carbohydrate $(10.04 \pm 0.002)$ were recorded for the healthy samples whereas fibre, lipid and protein were higher for the spoilt samples. Mineral composition showed the presence of calcium, phosphorus, potassium, iron, sodium and magnesium. All observed parameters were higher for the healthy samples of $\mathrm{P}$. sativum with an exception for iron which recorded equal concentrations $(4.0 \pm 0.001)$ for both healthy and spoilt samples. Vitamin compositions found in P. sativum were vitamins A, C, thiamine and niacin. They all had higher values for the healthy samples. Furthermore, P. sativum also contained anti-nutrient and phytochemicals such as phytate, oxalate, saponin, tannin, carotenoid, flavonoid, polyphenol and lignin in appreciable concentrations. Nevertheless, three fungal organisms viz: Slerotiumrolfsii, Mucorsppand Rhizopusstoloniferwere isolated and implicated for the spoilage of P. sativum. S. rolfsii had

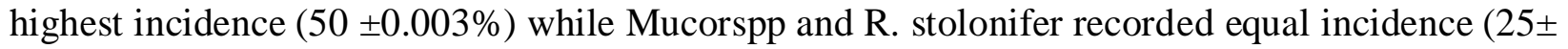
$0.023 \%)$.
\end{abstract}

Keywords: Mycoflora, Phaseolus vulgaris and nutritional constituents.

\section{INTRODUCTION}

Pisumsativum commonly known as green pea is an important legume that belongs to the Fabeceae family. The plant is an annual vegetable that prefers cold season, hence is mostly grown in the temperate region (Savage \&Deo, 1989; Zohany\&Hopf, 2000). P. sativum serves several curlinary purposes and it is widely consumed around the world. It can be boiled, dried or prepared as soup and salad. Due to its high demand, they are further processed and canned for future use (Sharma et al., 2015).

Just like every other legume, green pea is cherished because of its nutritional contents (Nguyen et al., 2015; Ganjlooet al., 2018). Literatures have shown that $P$. sativum possesses several proximate parameters such as moisture, ash, protein, fibre and many others (Upasana\&Vinay, 2018; Urbanoet al., 2003). Earlier studies have also shown the plant to contain calcium, iron, 
potassium, magnesium, phosphorus and several amino acids (Harmankayaet al., 2010; Igbasanet al., 1997; Amarakoon, 2012). Phytochemicals and vitamins have also been reported to be components of green pea (Xuet al., 2007; Duenaset al., 2004; Dahl et al., 2012). The research of Garg, (2015) also supported the nutritional value of $P$. sativum as he reported pea pod powder to contain proximate and mineral parameters. He also identified that the powder could be used for the preparation of Jaggerybiscuits.

Vegetables have always been prone to fungal attack, leading to spoilage and economic losses. In addition, filamentous fungi are vastly distributed and availably ready to cause contamination (Gourama, 2015). Kumar, (2015) implicated Fusariumoxysporum to be responsible for the spoilage of green pea pod sold in Panchgaon, India. Furthermore, Embabyet al., (2013) revealed several species of Aspergillus, Penicillium, Fusarium and Sclerotinia to contaminate three legume seeds including $P$. sativum. They also showed that these fungal organisms produced mycotoxins (aflatoxin and fumonisin) that were significantly high. This was supported byRamprasadet al., (2014) as they reported the menace of filamentous fungi on green pea and other vegetables.

It was based on this available literature this research was carried out to investigate the nutritional constituents and associated spoilage fungi of $P$. sativum sold in Port Harcourt.

\section{MATERIALS AND METHODS}

\section{Sample Collection}

Samples of healthy fruits of P.sativum and partially rotted fruits were bought from the Fruit Garden Market at D. Line Diobu Port Harcourt and brought to the Department of Plant Science and Biotechnology and sent to the Plant Pathology Laboratory for further studies.

\section{Mycological studies}

\section{Preparation of mycological medium}

Sterilization of conical flask, slides, Petri dishes and all the equipment needed for the experiment was carried out in the laboratory. The glass wares were sterilized in the oven at $120^{\circ} \mathrm{C}$ for an hour after washing with soap, while other equipment were surface sterilized with $70 \%$ ethanol to reduce microbial contamination (Agrios, 2005). Inoculating loops and scalpels were sterilized by dipping for 20 seconds in $70 \%$ ethanol and heated to red hot. The mycological medium used was Sabouraud Dextrose Agar prepared in a conical flask using the standard method. The mouth of the flask was plugged with non-absorbent cotton wool and wrapped with aluminium foil. The conical flask containing the mycological medium was autoclaved at $121^{\circ} \mathrm{C}$ and pressure of $1.1 \mathrm{~kg}$ $\mathrm{cm}-3$ for 15 minutes. The molten agar was allowed to cool to about $40^{\circ} \mathrm{C}$ and dispensed into Petri dishes at $15 \mathrm{mls}$ per plate and allowed to further cool and solidify.

\section{Isolation of fungi from partially rotted P.sativum fruits.}


One gram of samples showing visible signs of spoilage by moulds was cut from the healthy portions of the fruits up to the points where rot had established and inoculated onto Sabouraud Dextrose Agar in Petri dishes onto which ampicillin was added to hinder the growth of bacteria in triplicate. The inoculated plates were incubated for 5 days at ambient temperature of $25^{\circ} \mathrm{C} \pm$ $3^{\circ} \mathrm{C}$ (Baudoni, 1988; Chuku, 2009; Samson et al, 1981). The entire set up was observed for 7 days to ensure full grown organisms. Pure cultures of isolates were obtained after a series of isolations.

\section{Identification of fungal organisms from P.sativum}

Microscopic examination of fungal isolates was carried out by the needle mount method (Cheesebrough, 2000). The fungal spores were properly teased apart to ensure proper visibility. The well spread spores were stained with cotton blue in lacto phenol and examined microscopically using both the low and high power objective. The fungi were identified based on their spore and colonial morphology, mycelia structure and other associated structures using the keys of (Samson et al, 1981; Olds, 1983).

\section{Pathogenicity studies}

Pathogenicity studies was carried out on P.sativum to check if the fungi isolated from the rotted fruits were capable of causing spoilage on healthy fruits samples. The methods of (Agrios, 2005; Trigiano, 2004) was basically followed. The fungal isolates were introduced into healthy fruits and observed for seven days. The set up was monitored regularly for growth.

\section{Determination of nutrient components of fruits ofP.sativum}

Healthy and spoilt fruit samples of P.sativum were sent to the Food Science and Technology Laboratory for the determination of nutrient composition. The methods of AOAC, (2005) was used for the analysis.

\section{Determination of percentage incidence}

The percentage incidence of fungal occurrence was determined by the formular stated below (Nnaji\&Rao, 2017):

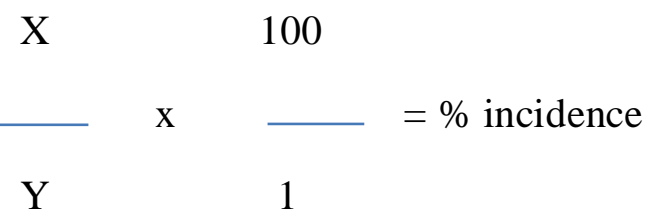

Where:

$\mathrm{X}=$ total number of each organism in a variety

$\mathrm{Y}=$ total number of all identified organism in a variety 


\section{RESULTS AND DISCUSSION}

Table 1: Proximate composition of healthy and spoilt samples of P.sativum

\begin{tabular}{|lll|}
\hline Parameters & Healthy (\%) & Spoilt (\%) \\
Moisture & $65.5 \pm 0.012$ & $64.2 \pm 0.011$ \\
Ash & $3.2 \pm 00.004$ & $3.1 \pm 0.022$ \\
Lipid & $1.75 \pm 0.001$ & $1.80 \pm 0.015$ \\
Carbohydrate & $10.04 \pm 0.002$ & $9.4 \pm 0.002$ \\
Fibre & $2.5 \pm 0.003$ & $3.0 \pm 0.013$ \\
Protein & $17.0 \pm 0.002$ & $18.5 \pm 0.020$ \\
\hline
\end{tabular}

Table 2: Mineral composition of healthy and spoilt samples of P.sativum

\begin{tabular}{|lll|}
\hline Parameters & Healthy $(\mathrm{mg} / 100 \mathrm{~g})$ & Spoilt $(\mathrm{mg} / 100 \mathrm{~g})$ \\
Calcium & $9.5 \pm 0.033$ & $7.5 \pm 0.021$ \\
Phosphorus & $7.5 \pm 0.005$ & $6.0 \pm 0.003$ \\
Potassium & $98 \pm 0.021$ & $96 \pm 0.005$ \\
Iron & $4.0 \pm 0.001$ & $4.0 \pm 0.001$ \\
Sodium & $3.5 \pm 0.001$ & $3.4 \pm 0.010$ \\
Magnesium & $5.5 \pm 0.005$ & $2.5 \pm 0.004$ \\
\hline
\end{tabular}

Table 3: Vitamin composition of healthy and spoilt samples of P.sativum

\begin{tabular}{|lll|}
\hline Parameters & Healthy $(\mathrm{mg} / 100 \mathrm{~g})$ & Spoilt $(\mathrm{mg} / 100 \mathrm{~g})$ \\
Vitamin A & $4.2 \pm 0.051$ & $2.5 \pm 0.010$ \\
Thiamin & $1.1 \pm 0.001$ & $0.9 \pm 0.006$ \\
Naicin & $0.7 \pm 0.002$ & $0.4 \pm 0.023$ \\
Vitamin C & $5.2 \pm 0.004$ & $2.05 \pm 0.003$ \\
\hline
\end{tabular}


Table 4: Anti-nutritional and phytochemical composition of healthy samples of P.sativum

\begin{tabular}{|ll|}
\hline Parameters & Healthy $(\mathrm{mg} / 100 \mathrm{~g})$ \\
Phytate & $0.03 \pm 0.002$ \\
Oxalate & $0.11 \pm 0.012$ \\
Saponin & $0.05 \pm 0.023$ \\
Tannin & $0.02 \pm 0.001$ \\
Carotenoid & $0.50 \pm 0.005$ \\
Polyphynol & $0.04 \pm 0.001$ \\
Flavonoid & $0.41 \pm 0.010$ \\
Lignin & $0.65 \pm 0.022$ \\
\hline
\end{tabular}

Table 5: Fungi isolates and their percentage incidence

\begin{tabular}{|ll|}
\hline Isolates & Percentage incidence (\%) \\
Sclerotiumrolfsii & $50 \pm 0.003$ \\
Mucorspp & $25 \pm 0.023$ \\
Rhizopusstolonifer & $25 \pm 0.023$ \\
\hline
\end{tabular}

The result for the proximate composition of healthy and spoilt $P$. sativum presented in Table 1 showed the presence of moisture, ash, lipid, carbohydrate, fibre and protein. The healthy samples of $P$. sativum recorded higher values for moisture (65.5 \pm 0.012$)$, ash $(3.2 \pm 0.004)$ and carbohydrate $(10.04 \pm 0.002)$ while lipid $(1.80 \pm 0.015)$, fibre $(3.0 \pm 0.013)$ and protein $(18.5 \pm$ $0.020)$ were higher for the spoilt samples. The proximate parameters assessed in this study confirmed the report of early findings (Savage \& De, 1989). Kumar, (2015) also evaluated the proximate composition of healthy and spoilt green pea. The carbohydrate and protein values as reported are lower than those found in this study for both healthy and spoilt $P$. sativum. However, the fibre concentrations of the present study are lower than those reported. The proximate parameters of the current study also agree with those investigated by Upasana\&Vinay, (2018) for the peel of green pea; even thoughhigher values for moisture $(83.41 \%)$, protein $(19.79 \%)$ and ash $(5.65 \%)$ were reported. Meanwhile, the lipid value recorded in this study is in line with the 1.2 to 2.4 lipid concentration reported by Dahl et al., (2012) for P. sativum. 


\section{International Journal of Agriculture, Environment and Bioresearch}

Vol. 4, No. 06; 2019

ISSN: $2456-8643$

Mineral composition of P.sativum presented in Table 2. revealed that calcium, phosphorus, potassium, iron, sodium and magnesium were present. The healthy samples recorded higher values for all the parameters assessed with an exception for iron which had equal values for both healthy and spoilt samples. The calcium and phosphorus values recorded in this study are higher than those reported by Igbasanet al., (1997) for twelve cultivars of green pea. Harmankayaet al., (2010) reported higher values for all the assessed parameters in this study. Nevertheless, the iron concentration $(4.0 \pm 0.001)$ of this present study conforms to the 2.19 to $5.84 \mathrm{mg} / 100 \mathrm{~g}$ range that was reported for several genotypes of green pea.

The result of vitamins composition presented in Table 3. indicated the presence of vitamins A, C, niacin and thiamin in both healthy and spoilt $P$. sativum. Higher values of $4.2 \pm 0.051,1.1 \pm$ $0.001,0.7 \pm 0.002$ and $5.2 \pm 0.004$ were recorded for vitamin $\mathrm{A}$, thiamin, niacin and vitamin $\mathrm{C}$ respectively for the healthy samples. The presences of these vitamins have been reported earlier in P. sativum (Savage \&Deo, 1989). Higher values of these vitamins have also been reported by early researchers in green pea (Robertson \&Sissons, 1986; Wills et al., 1984).

The result of anti-nutrients and phytochemicals of green pea presented in Table 4.showed the presence of phytate, oxalate, saponin, tannin, carotenoid, polyphenol, flavonoid and lignan. The result of the current study is in agreement with earlier works anti-nutrients and phytochemicals have been associated with several legumes including green pea (Elkowicz\&Sosulski, 1982). The research of Martens et al., (2017) also showed the presence of phytochemicals in P. sativum and the flavonoid concentration in this study is in line with the 0.45 and 0.43 they reported.

The nutritional quality of $P$. sativum cannot be overlooked as these parameters are necessary and vital for healthy living. Inasmuch as it serves as a source of amino acids (protein), energy (carbohydrate) and fibre; it can also support the body immune system as phytochemicals possess antimicrobial and anticarcinogenic activities (Campos-Vega et al., 2010; Mathers, 2002; Martens et al., 2017).

Three fungal organisms viz: Sclerotiumrolfsii, Mucorspp and Rhizopusstolonifer as presented in Table 5. were isolatedand implicated through pathogenicity test to cause spoilage of P. sativum. Highest percentage incidence $(50 \pm 0.003)$ was recorded for $S$. rolfsii while Mucor and Rhizopusrecorded equal incidence $(25 \pm 0.23)$. The isolates of this present study disagrees with Kumar, (2015) as he implicated only $F$. oxysporum to be responsible for the spoilage of green pea. Furthermore, the isolation of $S$. rolfsii is in line with the Sclerotinasclerotiorum reported by Embabyet al., (2013).The occurrence and equal incidence of Mucor and Rhizopus could be attributed to their taxonomic relationship as they both belong to the Mucorales order and are always associated with food spoilage (Salako\&Anjorin, 2012). The deteriorative activities of these organisms stand as a treat to the consumption of $P$. sativum.

\section{CONCLUSION}

Legume crops have always been referred to be rich in nutrient and the current study has shown that Pisumsativum is neither an exemption. However, the presence of spoilage organisms makes it unsafe for consumption and reduces its market values. Hence proper hygienic measures should be adopted to guide against contamination. 
Vol. 4, No. 06; 2019

ISSN: $2456-8643$

\section{REFERENCES}

A.O.A.C., (2005).Official Methods of Analysis of AOAC International. $18^{\text {th }}$ edition.Association of Official Analytical Chemists, Washington, D.C, USA.

Agrios, G. N., (2005). Plant Pathology, $5^{\text {th }}$ edition. Elsevier Academic Press, USA 383-557.

Amarakoon, R. (2012). Study on amino acid content in selected varieties of Pisumsativum (peas) by ion exchange chromatography. Int. Confr. Of Nutri.\& Food Sci. (IPCBEE), 39: 211214.

Baudoni, A.B.A.M., (1988). Diagnosis of disease and proof of pathogenicity (Koch's Postulate) in Laboratory exercises in Plant Pathology. An instructional kit, Baudoni.

Campos-Vega R., Loarca-Pina G. \&Oomah B. D. (2010).Minor components of pulses and their potential impact on human health.Food Res. Int., 43: 461-482.

Cheesebrough, M., (2000).District Laboratory Practice in Tropical Countries, Part 2.Cambridge University Press, London. 143- 156.

Chuku, E C., (2009). Fungi responsible for the spoilage of Plantain (Musa paradisiaca) at various ripening stages.ActaAgronomicaNigeriana, 9 (1\&2), 35- 40.

Dahl W. J., Foster L. M. \& Tyler R. T. (2012). Review of the health benefits of peas (Pisumsativum L.). Brtitish J. of Nutrition, 108: S3-S10.

Deunas M., Estrella I. \& Hernandez T. (2004).Occurrence of phenolic compounds in the seed coat and the cotyledon of peas (Pisumsativum L.).Eur. Food Res. Tech., 219: 116-123.

Elkowicz, Z. \&Sosulski, F. W. (1982). Antinutritive factors in eleven legumes and their airclassified protein and starch fractions. J. of Food Sci., 47: 1301-1304.

Embaby E. M., Mohamed R., Mosaas A. A., Hassan O. \&Asmaa M. M. (2013). Occurrence of toxigenic fungi and mycotoxins in some legume seeds.J. of Agric. Tech., 9(1): 151-164.

Ganjloo A., Bimakr M., Zarringhalami S., Jalili S. M. \&Ghorbani M. (2018).Moisture dependent physical properties of green peas (Pisumsativum L.).Int. Food Res. J., 25(3): 1246-1252.

Garg, M. (2015). Nutritional evaluation and utilization of pea pod powder for preparation of Jaggery biscuits. J. of Food Processing \& Tech., 6(12): 522.

Gourami, H. (2015).A preliminary mycological evaluation of organic and conventional foods. Food Protection Trends, 35(5): 385-391.

Harmankaya M., Ozcan M. M., Karadas S. \& Ceyhan E. (2010).Protein and mineral contents of pea (Pisumsativum L.) genotypes grown in central Anatolian region of Turkey.South Western J. of Hort., Bio and Env., 1(2): 159-165. 
Vol. 4, No. 06; 2019

ISSN: 2456-8643

Igbasan F. A., Guenter W. \&Slominski B. A. (1997). Field peas: chemical composition and energy and amino acid availabilities for poultry. Can. J. Anim. Sci., 77: 293-300.

Martens L. G., Nilsen M. M. \&Provan F. (2017). Pea hulfibre: Novel and sustainable fibre with important health and fractional properties. E. C. Nutrition, 10(4): 139-148.

Mathers, J. C. (2002). Pulses and carcinogenesis: Potential for the prevention of colon, breast and other cancers. British J. of Nutr., 88(3): 273-279.

Nguyen G. T., Gidley M. J. \&Sopade P. A. (2015).Dependence of in-vitro starch and protein digestions on particle size of field peas (Pisumsativum L.).LWT-Food Sci. \& Tech., 63: 541-549.

Nnaji P. T. and Rao A. P. (2017). Fungal contamination of locally processed Nigerian food (okpa): A threat to public health. Journal of Advances in Microbiology, 4(1):1-8.

Olds R. J., (1983). A colour Atlas of Microbiology, $5^{\text {th }}$ edition, Wolf Medical Publication Ltd., London 213.

Rampasad D., Debashish S. \&Bhattar S. (2014).Microbial examination of spoiled foods.Int. J. of Sci. Res., 3(8): 347-349.

Robertson, J. \&Sissons, D. J. (1987). The effects of maturity, processing, storage in the pod and cooking of the vitamin C content of free peas. Nutrition, 316: 21-27.

Salako, E. A. \&Anjorin, S. T. (2012).Principle of general mycology, $2^{\text {nd }}$ edition. Print Villa Publishers, pp69.

Samson, R.J, Hoeskstra, E. S and Van Oorschot, C.A.N., (1981). Introduction to food borne fungi.Centraal bureau coorSchmmel cultures, Netherlands. 16 -170.Publisher Institute of Royal, Netherland.

Savage, G. P. \&Deo, S. (1989). The nutritional value of peas (Pisumsativum): A literature review. Nutrition Abstracts \& Reviews (Series A), 59(2): 66-88.

Sharma S., Singh N., Singh V. A. \& Chand R. J. (2015). Quality traits analysis and protein profiling of field pea (Pisumsativum L.) germplasm from Himalayan region. Food Chemistry, 172: 528-536.

Trigiano, R. N, Windham, M. J and Windham, A.S., (2004).Plant Pathology concept and Laboratory exercise. C.R.C. Press L.L.C, USA. 345-359.

Upasana\&Vinay, D. (2018). Nutritional evaluation of pea peel and pea peel extracted byproducts. Int. J. of Food Sci. Nutri., 3(1): 65-67.

Urbano G., Aranda P., Elena G., Frejnagel S., Porres J. M., Frias J., Concepcion V. \& Maria L. (2003). Nutritional evaluation of pea (Pisumsativum L.) protein diets after mild 
International Journal of Agriculture, Environment and Bioresearch

Vol. 4, No. 06; 2019

ISSN: $2456-8643$

hydrothermal treatment and with and without added phytase. J. Agric. Food Chem., 51: 2415-2420.

Wills R. B. H., Evans T. J., Lim J. S. K., Scriven F. M. \& Greenfield H. (1984). Composition of Australian foods: 25 peas and beans. Food Tech. in Australia, 36: 512-514.

Xu B. J., Yuan S. H. \& Chang S. K. C. (2007).Comparative analyses of phenolic composition, antioxidant capacity and color of cool season legumes and other selected food legumes.J. Food Sci., 72: S167-S175.

Zohany, D. \&Hopf, M. (2000).Domestication of plants in the old world. Oxford: Oxford University Press. 